\title{
СОВРЕМЕННЫЕ ПРОБЛЕМЫ СТРАТЕГИЧЕСКОГО ПЛАНИРОВАНИЯ В РОССИЙСКОЙ ЭКОНОМИКЕ
}

\author{
(c) 2020 Чмышенко Елена Георгиевна \\ доктор экономических наук, профессор \\ E-mail: elenach2@yandex.ru \\ (c) 2020 Чмышенко Екатерина Владимировна \\ кандидат экономических наук, доцент \\ Оренбургский государственный университет, Россия, Оренбург \\ E-mail:minerva75@mail.ru
}

В статье рассматривается актуальность стратегического планирования как основной функции государственного управления. Представлены законы Российской Федерации, регулирующие данный процесс. Выявлены недостатки, связанные с отсутствием федерального органа, который бы координировал процесс стратегического планирования на разных уровнях управления. Проведен анализ основных показателей, характеризующих экономику России и развитых стран. Показана необходимость усиления подготовки специалистов в области стратегического планирования.

Ключевые слова: управление, законодательство, стратегическое планирование, прогнозирование, экономическое развитие

В современных условиях формирование конкурентоспособности страны и определение направлений развития в долгосрочной перспективе во многом определяется качеством государственного управления. Одной из важнейших функций, обеспечивающей качество управления, выступает стратегическое планирование. Объективная необходимость использования стратегического планирования связана с изменением парадигмы управления, отличительной чертой которой является отход от управления функционированием и переход к управлению развитием. Современная парадигма предполагает высокую компетентность руководителей всех уровней, переход на новые технологии в управлении, овладение новыми знаниями, позволяющими использовать конкурентные преимущества страны, определять приоритеты развития, привлекать инвестиционные ресурсы, создавать инновационные производства, повышать уровень и качество жизни населения.

Стратегическое планирование в России на федеральном и региональном уровнях стало развиваться с 2000-х годов. Наиболее значимыми научными работами в этой области являются труды В.П.Бауэра, А.В. Бузгалина, О.Б. Бухвалда, А.Г. Гранберга, .М. Гринчель, С.Ф.Жилкина, Б.С Жихаревича, К.Н.Знаменской, О.Б. Иванова, Г.Б. Клейнер, А.И. Колганова, О.В. Коломийченко, Ю.Н. Лапыгина, В.Н. Лекси- на, К.С. Львова, П.А. Минакира, В.М. Полтерович, В.Е. Селиверстова, О.О. Смирновой, Л.С. Шеховцевой, А.Н. Швецова, И.Е. Рисина, В.Е. Рохчина и других исследователей.

Актуальность и необходимость применения стратегического планирования обусловливается следующими причинами:

- глобализация мировых экономик;

- международное разделением труда;

- усиление процессов конкуренции за привлечение инвестиционных и финансовых ресурсов, высококвалифицированных трудовых ресурсов, туристических потоков и др.;

- быстрые темпы развития научно-технической революции, что ведет к быстрой смене технологий;

- необходимость перехода от индустриальной экономики на предпринимательскую;

- тупиковость сложившейся в России либерально-рыночной модели экономики, которая не обеспечивает инновационного развития страны.

Однако, несмотря на значительный рост публикаций и практических разработок, до сих пор ни за рубежом, ни в России не создана целостная научная школа стратегического планирования. В России это связано с тем, что формирование стратегического планирования как института осуществлялось в условиях перехода страны от централизованной модели управления к мо- 
дели управления в рыночной экономике, при отсутствии теоретико-методологической и методической базы, законодательных нормативно-правовых актов, практики реализации данного процесса.

В 1990-х годах века ХХ был упразднен Госплан СССР, и сам термин «планирование» исчез из официальных документов. На базе Госплана СССР в 1991 году было создано Министерство экономики и прогнозирования СССР. Утвердилось мнение, что регулирование экономических процессов и отношений, можно осуществлять с помощью прогнозирования экономико-математических моделей развития страны. Поэтому создание на федеральном уровне нового специализированного института планирования даже не рассматривалось.

Вкладом в решение проблемы стало принятие в 1995 году Закона РФ «О государственном прогнозировании и программах социально-экономического развития Российской Федерации» [4]. В соответствии с ним предполагалась многовариантная разработка государственных прогнозов социально-экономического развития надолго, средне- и краткосрочные перспективы.

Реформаторы того времени считали, что функцией планирования будут заниматься на уровне предприятий, а прогнозированием в соответствующих органах исполнительной власти (федеральной, региональной, отраслевой и муниципальной).

Субъектом прогнозирования на федеральном уровне стало выступать Министерство экономического развития и торговли, функция которого заключалась в прогнозировании социально-экономического развития, сводных финансовых балансов по Российской Федерации, субъектам, отраслям и секторам национальной экономики.

В 2004 году было сформировано Министерство регионального развития России, которому были переданы функции по организации разработки федеральных целевых программ регионального и территориального развития.

С этого периода начался первый этап по созданию бесчисленного множества планов-прогнозов. Названия этих документов были различные (стратегический план, стратегии развития, программы развития), а также они отличались по горизонтам планирования - до 2015, 2020 годов.

Однако, разразившийся в конце 2008 года финансово-экономический кризис отчетливо высветил самые уязвимые места множества перспективных прогнозов, что заставило руководство страны изменить взгляды на планирование.

В 2014 году был принят Федеральный закон «О стратегическом планировании в Российской Федерации».[5]. С принятием закона в стране начался второй этап бюрократической кампании по формальному выполнению требований закона - в сжатые сроки повсеместно и единообразно создать стратегии на всех уровнях. В 2015-2016-е годы Минэкономразвития России издало пятнадцать нормативно-правовых актов (НПА), регламентирующих порядок разработки, корректировки, мониторинга и реализации документов стратегического планирования на федеральном уровне [6].

Все субъекты планирования срочно приступили к корректировке и обновлению уже созданных стратегий. В кратчайший срок во всех субъектах федерации разработаны стратегии социально-экономического развития, несколько десятков отраслевых стратегий, тысячи муниципальных на период до 2030 года.

В результате в стране сформировалось огромное количество разноуровневых стратегических документов, которые должны были сформировать единую целостную систему многочисленных стратегических планов. Однако, на практике не были решены основные задачи: обеспечение согласованности стратегических планов между субъектами разных уровней и практическая их реализации.

Проведенная большая работа в области стратегического планирования со стороны государственных органов пока не привела к существенным изменениям в экономических процессах России. Остаются низкими темпы роста ВВП, который за последние годы обеспечивается, главным образом, за счет увеличения добычи и экспорта энергоносителей (табл. 1).

Как видно из данных табл. 1, после валютного кризиса России в 2014-2015 годах национальная экономика начала постепенно расти, однако темпы роста очень малы. Увеличение ВВП за последние три года (2016-2018 гг.) было обеспечено добычей полезных ископаемых, в основном за счет роста ценового фактора. Объем отгруженных товаров обрабатывающих производств имеет более низкие темпы роста, по сравнению с добывающими. Так, в 2018 году его рост соста- 
Таблица 1. Темпы роста ВВП, объемы добычи и экспорта энергоносителей в РФ [1]

\begin{tabular}{|l|c|c|c|c|c|}
\hline \multicolumn{1}{|c|}{ Показатель } & 2010 г. & 2015 г. & 2016 г. & 2017 г. & 2018 г. \\
\hline Темпы роста валового внутреннего продукта, \% & 4,5 & $-2,5$ & 0,3 & 1,5 & 2,2 \\
\hline $\begin{array}{l}\text { Объем отгруженных товаров собственного } \\
\text { производства, млрд. руб. } \\
\text { добыча полезных ископаемых }\end{array}$ & 6218 & 11171 & 11740 & 13916 & 18498 \\
\hline Добыча нефти, млн. т & & & & & 546 \\
\hline Добыча газа, млрд. м3 & 651 & 634 & 641 & 692 & 728 \\
\hline Добыча угля, млн. т & 322 & 372 & 386 & 411 & 448 \\
\hline Обрабатывающие производства, млрд. руб. & 18881 & 33087 & 34967 & 38733 & 43950 \\
\hline Экспорт всего, млрд. долларов США, в том числе: & 337 & 298 & 248 & 310 & 395 \\
\hline минеральные продукты & 242 & 201 & 156 & 199 & 271 \\
\hline машины, оборудование и транспортные средства & 21,3 & 25,4 & 24,5 & 28,1 & 19,3 \\
\hline
\end{tabular}

вил, по сравнению с 2016 годом, 25,7\%.

В 2018 году, по сравнению с 2016 годом, экспорт продукции увеличился на 147 млрд. долларов США (на 59,2\%) и в основном, за счет реализации минеральных продуктов (на 73,7\%). Необходимо отметить значительное снижение экспорта машин, оборудования и транспортных средств. Так, по сравнению с 2016 годом их экспорт снизился на 21,3\%, а в структуре экспорта на их долю приходится всего 5,3\%.

В России продолжается ухудшение структуры промышленного производства, уменьшается доля отраслей с высокой добавленной стоимостью. Так, в промышленном производстве устойчиво растет доля топливно-энергетического комплекса при сокращении доли машиностроения, в то время, как именно машиностроение выступает основным двигателем развития научно-технического прогресса и государства.

В настоящее время доля машин и оборудования в структуре российской обрабатывающей промышленности составляет 19,4\%, а в разви- тых странах эти цифры на порядок выше (табл. 2).

Отрасли с высокой добавленной стоимостью в стране продолжают разрушаться. В наибольшей степени это происходит в наукоемкой промышленности, где ведущая роль принадлежит машиностроению.

В России продолжает сокращаться производство основных видов продукции машиностроения, особенно производство тракторов, комбайнов, троллейбусов, автобусов, судов, кузнечно-прессового оборудования, оборудования для пищевой и легкой промышленности.

Представленные примеры российской экономической действительности, свидетельствуют о том, что экономика России не приобрела тенденций развития, а во многих отраслях и регионах продолжается спад производства и закрытие предприятий. Большие надежды правительства на стратегическое планирование как на инструмент управления, который должен был обеспечить инновационное развитие экономи-

Таблица 2. Фрагмент структуры обрабатывающих производств России и развитых стран, \% [2]

\begin{tabular}{|c|c|c|c|c|c|}
\hline Страна & Год & $\begin{array}{c}\text { Производство } \\
\text { Пищевых про- } \\
\text { дуктов }\end{array}$ & $\begin{array}{c}\text { Производство } \\
\text { кокса и нефте- } \\
\text { продуктов }\end{array}$ & $\begin{array}{c}\text { Металлургиче- } \\
\text { ское производ- } \\
\text { ство }\end{array}$ & $\begin{array}{c}\text { Производство } \\
\text { рудон и обо- }\end{array}$ \\
\hline Россия & $\mathbf{2 0 1 7}$ & $\mathbf{1 6 , 4}$ & $\mathbf{2 1 , 2}$ & $\mathbf{1 9 , 3}$ & $\mathbf{1 9 , 4}$ \\
\hline Германия & 2014 & 10,6 & 5,6 & 12,3 & 44,0 \\
\hline Республика Корея & 2011 & 4,9 & 9,8 & 16,0 & 46,0 \\
\hline Япония & 2012 & 12,2 & 6,3 & 13,8 & 42,2 \\
\hline Венгрия & 2013 & 12,8 & 9,4 & 7,3 & 43,5 \\
\hline Израиль & 2014 & 12,0 & $\ldots$ & 9,9 & 40,2 \\
\hline Румыния & 2015 & 16,7 & 4,6 & 10,8 & 35,7 \\
\hline Китай & 2014 & 11,0 & 4,3 & 16,7 & 33,3 \\
\hline СшА & 2015 & 16,8 & 9,2 & 6,3 & 31,7 \\
\hline Норвегия & 2013 & 24,4 & $\ldots$ & 11,5 & 28,4 \\
\hline
\end{tabular}


ки, не оправдались.

Это связано с тем, по мнению многих ученых, что внедрение стратегического планирования осуществлялось быстрыми темпами, без серьезной подготовки и проработки теоретических и методологических аспектов, изучения опыта западных стран по его внедрению. Поэтому в настоящее время требуется большая работа по совершенствованию данного инструмента.

По мнению авторов, проводивших анализ стратегий социально-экономического развития по шестнадцати регионам России, главный недостаток разработанных документов - это их низкое качество [8]. Этому способствует ряд причин, одной из основных является отсутствие специалистов по стратегическому планированию. Составление любого плана текущего, среднесрочного или стратегического во многом определяется компетенциями, профессионализмом, квалификацией и аналитическими способностями людей, которые его составляют.

В советское время приказом Минвуза СССР от 05.09.1975 № 831 «Об утверждении Перечня действующих специальностей и специализаций высших учебных заведений СССР» были определены следующие специальности: планирование народного хозяйства, планирование промышленности, планирование сельского хозяйства, экономика и планирование материально-технического снабжения, а также специальность экономика и организация для различных отраслей. И наряду с общей квалификацией «экономист», отдельно выделялась квалификация «экономист по планированию» [3].

В современных условиях подготовка экономистов в вузах осуществляется по направлению «Экономика», имеющему несколько профилей. Проведенный анализ ряда вузов (Санкт-Петербургский государственный экономический университет, Российский экономический университет им. Г.В. Плеханова, Самарский государственный экономический, Оренбургский государственный университет, Ульяновский государственный университет и др.), показал, что практически ни в одном из них нет отдельного профиля, связанного с подготовкой экономистов по планированию,

Наиболее часто встречаемые профили бухгалтерский учет, анализ и аудит, экономика предприятий и организаций, финансы и кредит, бизнес-статистика, мировая экономика, корпоративные финансы, ценообразование, налоги и налогообложение, математические методы, государственные и муниципальные финансы, экономика предпринимательства и др. Из рассмотренных вузов только в Российском экономическом университете имеется профиль, связанный с планированием - «Экономика и бизнес-планирование».

Отсутствие в вузах профилей по планированию объясняется и тем, что в стране резко снизился спрос на данных специалистов со стороны предприятий. У многих руководителей сложилось твердое убеждение, что планировать в условиях рыночной экономики не имеет никакого смысла. Так, проведенный Центральным экономико-математическим институтом РАН опрос руководителей 200 российских компаний (среди них были крупные, средние и мелкие), показал, что только половина из них формируют краткосрочные планы.

Таким образом, быстрый переход от директивного планирования к стратегическому, не позволил многим руководителям предприятий понять его значимость для развития бизнеса, разработчикам планов понять природу, смысл и содержание стратегического планирования, а правительству определиться с необходимостью подготовки в вузах профессиональных кадров в этом направлении. Как отметил д.э.н. А.Н. Швецов: «Становление стратегического планирования в России займет еще много времени, при условии серьезной и систематической работы, фундаментальным результатом которой должны стать теоретико-методологические основы, выражающие новый смысл и определяющие новые методы российского стратегического планирования» [6].

\section{Библиографический список}

1 Россия в цифрах. 2019: Крат. стат. сб./Росстат - М., 2019-549 с.

2 Россия и страны мира. 2018: Стат. сб./Росстат.-М., 2018-375 с.

3 Приказ Минвуза СССР от 05.09.1975 N831 «Об утверждении Перечня действующих специальностей и специализаций высших учебных заведений СССР» [Электронный ресурс].- Режим доступа: https://base. garant.ru/6579213/ 
4 Федеральный закон от 20.07.1995 г. № 115-Ф3 «О государственном прогнозировании и программах социально-экономического развития Российской Федерации» /«Собрание законодательства РФ», 24.07.1995.№ 30.- С. 2871.

5 Федеральный закон «О стратегическом планировании в Российской Федерации» от 28.06.2014 № $172-Ф 3$ (с изм. на 18 июля 2019 г.) [Электронный ресурс]. - Режим доступа: http://docs.cntd.ru/document/420204138

6 Швецов, А.Н. Деструктивные стереотипы российского стратегического планирования и их возможные последствия для практики регионального стратегирования (часть 1) / А.Н. Швецов, А.Н. Демьяненко, В.Н. Украинский. - Регионалистика. - 2016.- Т.3.- С.48-60.

7 Швецов, А.Н. Стратегическое планирование по-российски: торжество централизованного бюрократического выбора / А.Н. Швецов. - ЭКО. - 2017. - № 8. - С.114-127.

8 Стратегическое региональное планирование на основе технологий и инструментов маркетинга: монография / Е.В. Чмышенко, С. В. Панкова, Е.Г. Чмышенко; Оренбургский гос. ун-т. - Оренбург: ОГУ, 2013. - 170 с. 